\title{
Applying Robotics in School Education: a Systematic Review
}

\author{
Svetlana KUBILINSKIENE ${ }^{1,2}$, Inga ZILINSKIENE ${ }^{3}$, \\ Valentina DAGIENE ${ }^{1}$, Vytenis SINKEVIČIUS ${ }^{4}$ \\ ${ }^{1}$ Vilnius University Institute of Mathematics and Informatics, 4 Akademijos str., Vilnius 08663, \\ Lithuania \\ ${ }^{2}$ Vilnius kolegija / University of Applied Sciences, 58 Saltoniškių str., Vilnius 08105, Lithuania \\ ${ }^{3}$ Mykolas Romeris University, 20 Ateities str., Vilnius 08303, Lithuania \\ ${ }^{4}$ Kaunas University of Technology Panevėžys Faculty of Technologies and Business, 33 - 219 \\ Nemuno str., Panevėžys, Lithuania \\ s.kubilinskiene@eif.viko.lt, inga.zilinskiene@mruni.eu, \\ valentina.dagiene@mii.vu.lt, vytenis.sinkeviciusaktu.lt
}

\begin{abstract}
A modern learning environment can be developed by using innovative tools and methods. Benefits of robotics in teaching and learning processes have recently been drawing an increasing attention of researchers. The article aims are to perform a systematic review of the literature on the application of educational robots in schools, in order to identify the experience in the use of robotics in both formal primary, basic, and secondary schools and informal education, e.g. after school activities, summer camps. 16 relevant articles have been selected from the bibliographic databases as part of the systematic literature review. The analysis covers the following components of the articles: research aim, a curriculum taught by using robots, specific teaching methods, other characteristics (sample size, age limits and/or study cycle), and findings. The systematic literature review has shown that robotics has been paving its way as a teaching aid in a more intensive and flexible manner. The systematized findings of the literature review show the need for a further scientific research in this area in Lithuanian schools and may provide educators, practitioners and researchers, working in this area, with valuable guidelines.
\end{abstract}

Keywords: robotics, school education, application, systematic review, innovative tools, innovative approaches

\section{Introduction}

A modern learning environment can be developed by using innovative tools and methods. Benefits and efficiency of robotics in teaching and learning processes have recently been drawing an increasing attention of researchers. Theorists of education, e.g. Papert (1993), believe that robot-aided activities have great potential to improve classroom teaching, a child learns more effectively when he/she is actively engaged in the construction of objects of an outer world. Sullivan (2008) has emphasized that robot-involving setting and specific educational methods promote the development of cognitive and learning skills. The studies by Williams et al. (2007) have shown that 
robots, user manuals and instructions included into problem-solving activities could help pupils link the experience to scientific concepts. Robotics may become a modern teaching aid in various subjects by applying the respective educational methods.

Formation of skills in information technology, communication and algorithms, as well as education of algorithmic thinking by the LEGO technological method has been applied in non-formal education at Lithuanian schools since 2002. Educators have started generating ideas and developing this activity by introducing robotics into teaching of various subjects, since LEGO educational robots not only do inspire children's interest, but also promote scientific inquiry, subsequent verification of the findings and, in particular, enable children themselves to experiment with physical objects.

The research aim has been set based on the claims, found in the literature, stating that educational robots are adequate means to improve learning, namely, to perform a systematic review of the literature on the use of educational robots in schools in order to:

1. Identify the benefit provided by means of the educational robots as a teaching aid by pupils in various subjects, referred to in the research articles and provide the synthesis of empirical data to validate the benefit of learning aided by educational robots;

2. Present the synthesis of the described data on the diversity of teaching methods, aided by educational robots;

3. Identify the prospects for scientific research related to robotics in education.

The paper consists of four sections. The relevance of the paper and research issues are presented in the introduction section. The second section provides the research methodology and design following which the review has been performed. The results of the systematic review are presented in the third section. The last section presents overall results of the research done.

\section{Research Methodology and Design}

In order to identify the possibilities to use educational robots for educational goals, a basic systematic literature review method, devised by Kitchenham (2004), has been used. The following research questions have been raised to perform a systematic literature review by this method:

1 Question: Has the scope of use of robotics extended at schools today?

2 Question: Which teaching methods (teaching strategy) are applied when using robotics in the educational process?

The search for systematic reviews has been carried out in order to find some similar systematic reviews of the use of robotics in education. Only one study on this topic has been found by researcher Fabiane Barreto Vavassori Benitti at the Italian Univali University (Benitti, 2012). The review of the study by Benitti revealed the first characteristics of the use of robotics in education. The researcher chose peer-reviewed articles, published in English from 2000 to 2009. The article presented a comprehensive, systematic review encompassing the entire system of general education.

A systematic analysis to achieve the first aim of this study was made in January and March 2014. In the citation database Web of Science covers 5 international databases: (a) Science Citation Index Expanded (SCI-EXPANDED); (b) Social 
Sciences Citation Index (SSCI); (c) Arts \& Humanities Citation Index (A\&HCI); (d) Conference Proceedings Citation Index- Science (CPCI-S); (f) Conference Proceedings Citation Index- Social Science \& Humanities (CPCI-SSH). Only peerreviewed articles in English, published in 2012-2013 (studies during the recent two years), were chosen. The following key words were entered into the search box: (robotic AND curriculum) OR (robotic AND teaching) OR (robotic AND education) OR (robotic AND school). Table 1 presents the protocol on the citation database Web of Science.

Table 1. Search results in the database Web of Science.

\begin{tabular}{|c|c|}
\hline Results & Protocol \\
\hline 38 & $\begin{array}{l}(\mathrm{TS}=(\text { robotic AND curriculum })) \text { AND Language=(English) AND } \\
\text { Document Types }=(\text { Article }) \\
\text { Databases }=\text { SCI-EXPANDED, SSCI, A\&HCI, CPCI-S, CPCI-SSH } \\
\text { Timespan }=2012-2013\end{array}$ \\
\hline 76 & $\begin{array}{l}(\mathrm{TS}=(\text { robotic } \text { AND teaching }) \text { AND Language=(English) AND } \\
\text { Document Types }=(\text { Article }) \\
\text { Databases=SCI-EXPANDED, SSCI, A\&HCI, CPCI-S, CPCI-SSH } \\
\text { Timespan=2012-2013 }\end{array}$ \\
\hline 32 & $\begin{array}{l}(\mathrm{TS}=(\text { robotic AND school })) \text { AND Language=(English) AND } \\
\text { Document Types=(Article) } \\
\text { Databases=SCI-EXPANDED, SSCI, A\&HCI, CPCI-S, CPCI-SSH } \\
\text { Timespan=2012-2013 }\end{array}$ \\
\hline 84 & $\begin{array}{l}((\mathrm{TS}=(\text { robotic AND education }))) \text { AND Language=(English) AND } \\
\text { Document Types=(Article }) \\
\text { Databases=SCI-EXPANDED, SSCI, A\&HCI, CPCI-S, CPCI-SSH } \\
\text { Timespan }=2012-2013\end{array}$ \\
\hline
\end{tabular}

The following four criteria were used to filter the articles: AQn, $n=1,2,3,4$ :

AQ1: Robotic technologies used as a teaching aid rather than a subject.

AQ2: The article presents quantitative or qualitative feedback information on learning.

AQ3: Use of robots by a direct contact rather than online is described.

AQ4: The study field covers both formal pre-school education, elementary, basic, and secondary schools and informal education, e.g. after school activities, summer camps, etc. The article does not analyze a different context, e.g. undergraduate setting.

The search required to make a systematic literature analysis by stages. The first stage was aimed at finding all articles on robotics published during 2012-2013. Its total result was 230 articles found. The second stage was dedicated to the analysis of titles and abstracts subject to filtering by the mentioned criteria. Nonetheless, the elimination of articles would have been difficult to implement by a mere analysis of abstracts due to the specific nature of criteria. It was therefore decided to search for more information in the body of the articles. As a result, the articles that meet the set criteria (AQn) were selected by their comprehensive analysis made as the third stage of the search. Table 2 presents the number of articles at the end of each stage of the selection procedure. 
Table 2. Results of the process of article selection.

\begin{tabular}{|c|c|c|c|}
\hline Database & Search result: stage 1 & Selection: stage 2 & Selection: stage 3 \\
\hline $\begin{array}{c}\text { Web of } \\
\text { Science }\end{array}$ & $\begin{array}{c}230 \text { (with re-published } \\
\text { papers) }\end{array}$ & 22 & 16 \\
\hline
\end{tabular}

The paper also has some limitations. The first limitation of the systematic review is the selection of WoS database. Although the WoS database is not very appropriate for highly developing domains since it takes relatively long time for a publication to be included, the authors of the paper decided to choose that DB because of its importance in Lithuania. As a result, many recent works in this domain are excluded from the analysis. The second limitation arises because of validity of the findings in the study. The authors do not provide any reliability of article selection using the Cohen Kappa statistic, etc.

It must be noticed that not all articles provide accurate empirical results on which findings could be generalized. As a result, there is lack research of deep empirical studies of effectiveness and efficiency of robotics aided teaching and learning.

\section{Results of a Systematic Review}

This section analyses the results of a systematic review in order to answer the two research questions raised for the research.

\subsection{Summary of Research Methods found in Selected Papers}

The results found in selected papers are compared to that of the systematic analysis made by Benitti (2012). During the systematic review, Benitti has performed a search in six bibliographic databases and found 70 articles on the effective use of robots as a teaching aid, only ten of which provided a quantitative evaluation that enabled conducting the feasibility study on the use of robotics as a teaching aid at schools.

At the beginning of 2014, based on the given research methodology, 16 relevant articles have been selected from the bibliographic databases as part of the systematic literature review. 3 articles (Lye et al., 2013, Altin et al., 2013, Riojas et al., 2012) were under a particular focus, but did not fall within the scope of the article review due to their failure to comply with the criterion AQ2. Nonetheless, these articles may help answer the $3^{\text {rd }}$ research question, as they describe the actual application of robotics and validate the necessity of development of further experimental activities. These articles provide theoretical guidelines and teaching methods applicable to use of robotics in the educational process. A short review of the selected papers is presented in Table 3. 
Table 3. Short presentation of the selected papers.

\begin{tabular}{|c|c|c|}
\hline The aim of the source & $\begin{array}{l}\text { Research } \\
\text { method* }\end{array}$ & Source \\
\hline $\begin{array}{l}\text { The paper proposes a model of integrative teaching of } \\
\text { science and technology through practice which involves the } \\
\text { learner in exploration of a biological system and construction } \\
\text { of a robotic model. The main idea of the paper is } \\
\text { consideration of integrative teaching as a way to get } \\
\text { knowledge of concepts from different science disciplines } \\
\text { through applied learning experiences. The paper deals with } \\
\text { the study of reactive behaviors, i.e. behaviors manifesting } \\
\text { responses of biological and robotic systems to external } \\
\text { events. }\end{array}$ & $\mathrm{OY}$ & $\begin{array}{l}\text { Cuperman } \\
\text { et al., } 2013\end{array}$ \\
\hline $\begin{array}{l}\text { The paper presents a study on investigating the } \\
\text { effectiveness of an applied behavior analysis (ABA)-based } \\
\text { intervention conducted by a robot compared to an ABA- } \\
\text { based intervention conducted by a human trainer. The } \\
\text { research focuses on promoting self-initiated questions of } \\
\text { children with autism spectrum disorder. }\end{array}$ & $\mathrm{Z}$ & $\begin{array}{l}\text { Huskens et } \\
\text { al., } 2013\end{array}$ \\
\hline $\begin{array}{l}\text { This study investigates the use of robotic technology for } \\
\text { promoting attention, communication and social skills in } \\
\text { adolescents with autism spectrum disorder. }\end{array}$ & $\mathrm{O}$ & $\begin{array}{ll}\text { Jordan } & \text { et } \\
\text { al., } 2013 & \end{array}$ \\
\hline $\begin{array}{l}\text { The paper focuses on investigation of the architecture or } \\
\text { structure of problem solving language in children's } \\
\text { interactions with others, and with new cultural and } \\
\text { technological tools. }\end{array}$ & $\mathrm{OX}$ & $\begin{array}{l}\text { Mills et al., } \\
2013\end{array}$ \\
\hline $\begin{array}{l}\text { The objective was to evaluate the use of a robot teaching } \\
\text { assistant (RTA) effects to enhance and sustain learning } \\
\text { motivation for the learning of English reading skills. }\end{array}$ & $\mathrm{Z}$ & $\begin{array}{l}\text { Hung et al., } \\
2013\end{array}$ \\
\hline $\begin{array}{l}\text { The aim of this paper is the investigation of a behavior- } \\
\text { based application to programming robots and design of } \\
\text { robotic-centered courses and other outreach activities. }\end{array}$ & $\mathrm{X}$ & $\begin{array}{l}\text { De } \\
\text { Cristoforis } \\
\text { et al., } 2013\end{array}$ \\
\hline $\begin{array}{l}\text { This paper introduces the ZR (SPHERES Zero Robotics) } \\
\text { web tools, assesses the educational value delivered by the } \\
\text { program, using space and games, and evaluates the utility of } \\
\text { collaborative gaming within this framework. }\end{array}$ & $\mathrm{XZ}$ & $\begin{array}{l}\text { Nag et al., } \\
2013\end{array}$ \\
\hline $\begin{array}{l}\text { The paper presents the Victorian Space Science } \\
\text { Education Centre (VSSEC) as an institution for innovative } \\
\text { education and research. Outcomes of the Centre are used in } \\
\text { the development of education programs that: engage students } \\
\text { in STEM (Science Technology, Engineering, and } \\
\text { Mathematics); develop a deep understanding of fundamental } \\
\text { concepts in these areas; and develop the } 21 \text { st century skills } \\
\text { such as critical thinking, problem solving, collaboration, } \\
\text { communication, and the use of Information and } \\
\text { Communication Technologies. Some of these outcomes are } \\
\text { explored using the development of the Robotic Mission to } \\
\text { Mars program as an example. }\end{array}$ & $\mathrm{XY}$ & $\begin{array}{l}\text { Mathers et } \\
\text { al., } 2012\end{array}$ \\
\hline $\begin{array}{l}\text { The paper analyzed the results of a pilot project in } \\
\text { educational robotics. The purpose of the pilot project was } \\
\text { twofold: (1) to try the phase model for teaching and learning } \\
\text { of the robotics software in the early years context and (2) to }\end{array}$ & OXYZ & $\begin{array}{l}\text { McDonald } \\
\text { et al., } 2012\end{array}$ \\
\hline
\end{tabular}




\begin{tabular}{|c|c|c|}
\hline The aim of the source & $\begin{array}{l}\text { Research } \\
\text { method* }\end{array}$ & Source \\
\hline \multicolumn{3}{|l|}{$\begin{array}{l}\text { develop valid and authentic data collection methods and } \\
\text { means for analysis of the data. }\end{array}$} \\
\hline $\begin{array}{l}\text { The paper presents and discusses about a new summer- } \\
\text { camp-based program for in-school sessions, focused on } \\
\text { LEGO robotics to foster interest in STEM topics at a young } \\
\text { age. }\end{array}$ & $\mathrm{XY}$ & $\begin{array}{l}\text { Varney et } \\
\text { al., } 2012\end{array}$ \\
\hline $\begin{array}{l}\text { The paper presents the results of a small-scale qualitative } \\
\text { study that explored (1) the similarities and differences in } \\
\text { strategies adopted by teachers in the different schools in } \\
\text { implementing the mechatronics program (2) the influence of } \\
\text { external factors (such as infrastructure and resources) and } \\
\text { intrinsic factors (such as content knowledge and personal } \\
\text { attributes e.g. attitudes and confidence) on the outcomes of } \\
\text { the implementation. }\end{array}$ & $\mathrm{OY}$ & $\begin{array}{l}\text { Nicholas et } \\
\text { al., } 2012\end{array}$ \\
\hline $\begin{array}{l}\text { The paper describes a collaborative learning project, } \\
\text { which aims at involving college students with the } \\
\text { intermediate school students into LEGO (R) activities, since } \\
\text { the latter can increase their interest level in STEM fields. }\end{array}$ & & $\begin{array}{l}\text { Meyers et } \\
\text { al., } 2012\end{array}$ \\
\hline $\begin{array}{l}\text { The aim of this paper is to present the usage "of } \\
\text { alternative interface modalities to engage students with visual } \\
\text { impairments in robotics-based programming activities. We } \\
\text { provide an overview of the interaction system and results on } \\
\text { a pilot study that engaged nine middle school students with } \\
\text { visual impairments during a two-week summer camp." }\end{array}$ & $\mathrm{Z}$ & $\begin{array}{l}\text { Howard et } \\
\text { al., } 2012\end{array}$ \\
\hline $\begin{array}{l}\text { The study was conducted on the Kindergarten Social } \\
\text { Assistive Robotics (KindSAR). This is a novel technology } \\
\text { that offers the kindergarten staff an innovative tool for } \\
\text { achieving educational aims through social interaction. The } \\
\text { presented experiment was designed to examine how } \\
\text { KindSAR can be used to engage preschool children in } \\
\text { constructive learning. }\end{array}$ & $\mathrm{OZ}$ & Fridin, 2014 \\
\hline $\begin{array}{l}\text { This paper deals with the TangibleK Robotics Program in } \\
\text { order to determine whether kindergarten boys and girls were } \\
\text { equally successful in a series of building and programming } \\
\text { tasks. }\end{array}$ & $\mathrm{OY} \mathrm{Z}$ & $\begin{array}{l}\text { Sullivan et } \\
\text { al., } 2013\end{array}$ \\
\hline $\begin{array}{l}\text { The objective of the paper was to evaluate the impact of } \\
\text { three innovations (using robots in STEM education). The } \\
\text { main results confirmed that there is a powerful, cheap, robust, } \\
\text { and small advanced personal robot; it makes the basis of a } \\
\text { problem-based learning curriculum; and it enables us to } \\
\text { develop a novel multi-robot curriculum while fostering } \\
\text { collaborative team work on assignments. }\end{array}$ & $\mathrm{OXY}$ & $\begin{array}{l}\text { McLurkin et } \\
\text { al., } 2013\end{array}$ \\
\hline
\end{tabular}

* Research methods found in 16 selected papers: $X$ - students' self-reports as an evidence, $\mathrm{Y}$ - teachers' or mentors' observations, $\mathrm{Z}$ - validated tests to measure the effect, $\mathrm{O}$ observational classroom data: audio recording of participant interactions.

In the following sections each research question is considered severally. 


\subsection{Has the scope of use of robotics extended at school today?}

This research question refers to the change of a variety of subjects, types of robots used, pupils age groups in both formal and informal education found in the publications in the period $2012-2013$.

\section{Extension of robotics technologies and the range of learners}

In recent years, the rapid development of robotics technologies developed numerous tools on offer. The analysis of articles, included into the systematic review, has shown that various models of Lego robots (44\%) are used in learning activities. Only one article covered a quantitative evaluation of robots as teaching aids by using 4 robot platforms: Khepera robot, YAKS Khepera simulator, ExaBot robot Player/Stage simulator for the ExaBot robot and robot behavior-based interface developed by the researchers (De Cristoforis et al., 2013). The projects of four scientific studies offered achieving certain learning outcomes by robot kits other than Lego. The researchers proposed to develop biological phenomena and analyze trees by using PicoCricket kits and implementing alternative learning methods: "to combine art and technology, provide possibilities of creation of art by young people, develop links not only between motion, but also light, sound and music" (Cuperman et al., 2013). Two scientific studies employed SPHERES Zero Robotics (Nag et al., 2013) and Robotic Mission to Mars kits (Mathers et al., 2012) for the learning about space. The researchers offered using UniBoard devices and PICAXE microcontrollers for teaching mechatronics (Nicholas et al., 2012). The researchers of four scientific studies used humanoid robots for social interaction, socialization, communication (with autistic children) and development of speaking skills (Huskens et al., 2013; Jordan et al., 2013; Hung et al., 2013; Fridin, 2014). However, the learning activity, covered in the review by Benitti, was predominantly (90\%) implemented by using various models of Lego robots (Benitti, 2012). This fact suggests that the diversity of robotic tools used in the educational process is growing.

Table 4. Used types of robots.

\begin{tabular}{|c|c|c|}
\hline Tools & $\begin{array}{c}\text { Benniti (\% in papers } \\
\text { found) }\end{array}$ & $\begin{array}{l}\text { This study } \\
(\%)\end{array}$ \\
\hline $\begin{array}{l}\text { LEGO (NXT, RCX, Evobot, } \\
\text { Mindstorms, WeDo) }\end{array}$ & 90 & 43.8 \\
\hline PicoCricket & - & 6.25 \\
\hline SPHERES Zero Robotics & - & 6.25 \\
\hline $\begin{array}{l}\text { Khepera robot, YAKS } \\
\text { simulator, ExaBot repera } \\
\text { Player/Stage simulator for the } \\
\text { ExaBot robot (created by the } \\
\text { authors) }\end{array}$ & - & 6.25 \\
\hline $\begin{array}{l}\text { AEMRM: Autonomous } \\
\text { Educational Mobile Robot } \\
\text { Mediator (created by the authors) }\end{array}$ & 10 & - \\
\hline Robotic Mission to Mars & - & 6.25 \\
\hline $\begin{array}{l}\text { UniBoard devices and PICAXE } \\
\text { microcontrollers }\end{array}$ & - & 6.25 \\
\hline Humanoid robots & - & 25 \\
\hline
\end{tabular}


Depending on the research participants, the learners, covered in the systematic review, ranged from kindergarten age to senior classes, i.e. learners aged from 3 to 19. In his review, Benitti noted the lack of studies covering the usage of robots as a teaching aid for children of kindergarten age and 11-12 graders. Benitti has assumed that the lack of research on the use of robots in kindergartens was due to the minimum age (7 years) limitation on the Lego robot kit, which did not prove true, as two studies (Sullivan et al., 2013; McDonald et al., 2012) clearly use Lego kits in order to identify the role of technology in early childhood education. Another study, focusing on early childhood, deals with the effect of the new technology offered to professionals in kindergarten education - humanoid robot, based on social interaction and providing aid to the staff for engaging children in educational games (Fridin, 2014).

Three studies were conducted on upper secondary school pupils (Cuperman et al., 2013; De Cristoforis et al., 2013; Nag et al., 2013). Thus, the learners' age range has expanded in both directions, covering children of kindergarten age and elder pupils. Most experiments, involving the educational robots, were not included into the classroom activities, i.e. they are usually used in the after-school or summer camp program. Exceptions were introduced by five articles, one of which noted that teachers integrated their work into conventional teaching (Varney et al., 2012;), three articles described the use of robots by teachers in one of their classes (Mills et al., 2013; McDonald et al., 2012; Fridin, 2014), while the remaining article evaluated different methods of implementing of the program into the educational curriculum of 5 schools (Nicholas et al., 2012).

The situation is very similar to the findings of the review by Benitti. Four articles presented an exception: three articles noted that teachers could have integrated their work into conventional teaching, another article dealt with use of robots in one of their classes (Benitti, 2012). The difference is not significant, but there is an obvious tendency of inclusion of the robotics into classroom activities and the establishment of links between the robotics and curriculum.

\section{Application of robotics technologies for different subjects}

The progress of robotic technologies provides possibilities for implementing various learning activities in the subjects related not only to STEM. The majority of the studies covered in the review by Benitti $(80 \%)$, were focused on the topics related to physics and mathematics. The articles described the actual experience in teaching Newton's law, distance, angles, kinematics, graphic construction and explanation, functions, and geospatial concepts (Benitti, 2012). Findings by the authors of this study have suggested that $69 \%$ of studies have dealt with topics related to STEM (science, technology, engineering, mathematics).

Four studies moved beyond natural sciences: two studies were related to education of social skills of communication in autistic persons (Huskens et al. and Jordan et al., 2013), one study was related to education of social and cognitive skills in kindergarten (Fridin, 2014); while the fourth study dealt with the use of robotics in developing English reading skills (Hung et al., 2013); robotics is used as a tool in the study by Mills, but it is not the object of the study. The study analyses the structure of children's speech according to the problem-solving methodology by applying robots as a teaching aid in STEM. (Mills et al., 2013). McDonald (McDonald et al., 2012) analyzed topics related to STEM subjects, but obtained positive results and the effect 
on the social skills of communication. Only two studies, covered by Benitti in his review, are noteworthy to be considered, as they have moved beyond the area of natural sciences: the first study deals with use of robotics in teaching the basic principles of evolution, while another study deals with the development of social skills of communication in autistic persons (Benitti, 2012). This information suggests that applicability of robotics in schools is expanding and encompasses non-STEM subjects, such as subjects in the social sciences and humanities.

The study has shown that use of educational robots for improving of academic achievements is an effective and powerful tool in the area of STEM (science, technology, engineering, mathematics) notions (Table 5).

Table 5. Robotics as a powerful tool for understanding concepts in STEM.

\begin{tabular}{|c|c|c|}
\hline \multicolumn{2}{|r|}{ Subject domain } & Source \\
\hline \multicolumn{2}{|c|}{ Biology } & \\
\hline Topic & $\begin{array}{l}\text { modelling biological systems: a } \\
\text { venus flytrap model; a heart } \\
\text { functional model; the plant model }\end{array}$ & Cuperman et al., 2013 \\
\hline \multicolumn{2}{|c|}{ Technology / Engineering } & $\begin{array}{l}\text { Cuperman et al., 2013; Nag et al., } \\
\text { 2013; McLurkin et al., } 2013\end{array}$ \\
\hline \multirow[t]{4}{*}{ Topic } & $\begin{array}{l}\text { basic programming concepts (Loops, } \\
\text { conditions, forks, or variables); it } \\
\text { covers the basic concepts of } \\
\text { behavior-based robotics }\end{array}$ & $\begin{array}{l}\text { De Cristoforis et al., 2013; Varney et } \\
\text { al., 2012; Howard et al., } 2012\end{array}$ \\
\hline & $\begin{array}{l}\text { basic engineering concepts (e.g., } \\
\text { cam, gear, and crown gear) }\end{array}$ & McDonald et al., 2012 \\
\hline & $\begin{array}{l}\text { electricity, force, magnetism, and } \\
\text { simplified concepts in electronics }\end{array}$ & $\begin{array}{l}\text { Varney et al., 2012; Nicholas et al., } \\
2012\end{array}$ \\
\hline & $\begin{array}{l}\text { programming syntax, function of the } \\
\text { main, comments, compiling, } \\
\text { downloading code to the robot; } \\
\text { Sequential programming, variables, } \\
\text { functions (robot command library); } \\
\text { Debugging skills }\end{array}$ & $\begin{array}{l}\text { Howard et al., 2012; Sullivan et al., } \\
2013\end{array}$ \\
\hline \multicolumn{2}{|c|}{ Mathematics } & $\begin{array}{l}\text { Nag et al., 2013; Mathers et al., 2012; } \\
\text { McLurkin et al., } 2013\end{array}$ \\
\hline \multirow[t]{3}{*}{ Topic } & $\begin{array}{l}\text { various mathematical and logical } \\
\text { concepts }\end{array}$ & De Cristoforis et al., 2013 \\
\hline & numbers, counting & McDonald et al., 2012 \\
\hline & $\begin{array}{l}\text { mathematical concepts } \\
\text { (multiplication, ratios, and fractions) }\end{array}$ & Varney et al., 2012 \\
\hline \multicolumn{2}{|c|}{ Physics } & Nag et al., 2013; Nicholas et al., 2012 \\
\hline \multirow[t]{3}{*}{ Topic } & $\begin{array}{l}\text { mission to Mars, Mission to the } \\
\text { Orbiting Space Laboratory programs } \\
\text { deliver curriculum outcomes for } \\
\text { Year } 9 \text { and } 10 \text { students }\end{array}$ & Mathers et al., 2012 \\
\hline & $\begin{array}{l}\text { primary Expedition to the M.A.R.S. } \\
\text { Base supports the Year } 5 \text { and } 6 \\
\text { curricula }\end{array}$ & Mathers et al., 2012 \\
\hline & $\begin{array}{l}\text { rotation, speed, energy, and energy } \\
\text { conversion }\end{array}$ & Varney et al., 2012 \\
\hline
\end{tabular}


Based on the results of the systematic review areas of Lithuania's curriculum in which educational robots suggested to be applied is presented in table 6. It was found that benefits of the use of educational robots as teaching aid for social, arts, moral education still need more research. Other areas already have been considered by researchers. Therefore, more detailed assessment tools for evaluation of effectiveness and efficiency of educational robots aided teaching and learning must be developed for each area and applied to large samples.

Table 6. Suggestions to use educational robots in Lithuania

\begin{tabular}{|c|c|c|}
\hline $\begin{array}{c}\text { Areas of } \\
\text { Curriculum }\end{array}$ & $\begin{array}{l}\text { Main subjects of general education } \\
\text { (primary, basic and secondary) } \\
\text { programme in Lithuania }\end{array}$ & $\begin{array}{l}\text { The use of } \\
\text { educational } \\
\text { robots }\end{array}$ \\
\hline Languages & $\begin{array}{l}\text { Primary, basic and secondary education subjects: } \\
\text { Lithuanian language and literature, another } \\
\text { mother tongue, foreign languages }\end{array}$ & $\begin{array}{l}\text { Yes, for primary } \\
\text { and basic education }\end{array}$ \\
\hline $\begin{array}{l}\text { Mathematics } \\
\text { (STEM) }\end{array}$ & $\begin{array}{l}\text { Primary, basic and secondary education subjects: } \\
\text { mathematics }\end{array}$ & Yes \\
\hline $\begin{array}{l}\text { Science } \\
\text { education } \\
\text { (STEM) }\end{array}$ & $\begin{array}{l}\text { Basic and secondary education subjects: biology, } \\
\text { chemistry, physics, integrated natural sciences } \\
\text { course }\end{array}$ & $\begin{array}{l}\text { Yes, for biology } \\
\text { and physics }\end{array}$ \\
\hline Social education & $\begin{array}{l}\text { Basic and secondary education subjects: history, } \\
\text { geography, history and geography integrated rate } \\
\text { law, religious studies, philosophy, economics } \\
\text { and entrepreneurship, psychology, civic } \\
\text { education }\end{array}$ & $\begin{array}{l}\text { Needs more } \\
\text { Research }\end{array}$ \\
\hline Arts education & $\begin{array}{l}\text { Primary, basic and secondary education subjects: } \\
\text { art, music, dance, theater, graphic design, film- } \\
\text { making, photography, computer music } \\
\text { technology, and contemporary art }\end{array}$ & $\begin{array}{l}\text { Needs more } \\
\text { Research }\end{array}$ \\
\hline $\begin{array}{l}\text { Information } \\
\text { technologies } \\
\text { (STEM) }\end{array}$ & $\begin{array}{l}\text { Basic and secondary education subjects: } \\
\text { Information Technology }\end{array}$ & $\begin{array}{l}\text { Yes, for primary } \\
\text { education as well }\end{array}$ \\
\hline $\begin{array}{l}\text { Technologies } \\
\text { (STEM) }\end{array}$ & $\begin{array}{l}\text { Basic and secondary education subjects: } \\
\text { technology, integration of technology, } \\
\text { construction and wood processing, light industry, } \\
\text { applied arts, and so on. }\end{array}$ & $\begin{array}{l}\text { Yes, for } \\
\text { Engineering }\end{array}$ \\
\hline $\begin{array}{l}\text { Physical } \\
\text { education }\end{array}$ & $\begin{array}{l}\text { Primary, basic and secondary education subjects: } \\
\text { physical education, the chosen sport (basketball, } \\
\text { volleyball, etc.) }\end{array}$ & No \\
\hline Moral education & $\begin{array}{l}\text { Primary, basic and secondary education subjects: } \\
\text { ethics, Catholicism, Orthodox (Orthodox) } \\
\text { religion, Evangelical Lutheran religion, } \\
\text { Protestant reformers, Karaime religion, the } \\
\text { Jewish religion }\end{array}$ & $\begin{array}{l}\text { Needs more } \\
\text { Research }\end{array}$ \\
\hline $\begin{array}{l}\text { General } \\
\text { competencies }\end{array}$ & $\begin{array}{l}\text { Basic and secondary education subjects: human } \\
\text { safety }\end{array}$ & Yes \\
\hline $\begin{array}{l}\text { Cognition of the } \\
\text { world }\end{array}$ & $\begin{array}{l}\begin{array}{l}\text { Primary education subjects: } \\
\text { knowledge }\end{array} \\
\end{array}$ & Yes \\
\hline $\begin{array}{l}\text { Education for the } \\
\text { deaf and hard of } \\
\text { hearing }\end{array}$ & $\begin{array}{l}\text { Primary education subjects: Lithuanian sign } \\
\text { language, Lithuanian language, mathematics, } \\
\text { natural science }\end{array}$ & Yes \\
\hline
\end{tabular}




\section{Application of robotics technologies for different skills development}

In terms of skill development by using robotics, the skills formed are directed towards the following skills: (1) cognitive skills (observation, evaluation and manipulation), (2) educational process skills/problem-solving methods (e.g., evaluative solution, generation of hypotheses and control of the variables), (3) social interaction/team work skills, (4) motor skills and (5) reading, writing, and computational skills (Table 7).

Table 7. Robotics as a tool for developing non STEM subjects and different skills.

\begin{tabular}{|l|l|}
\hline \multicolumn{1}{|c|}{ Skills } & \multicolumn{1}{c|}{ Source } \\
\hline Acquired skills of learning with models & Cuperman et al., 2013 \\
\hline Reasoning skills & Cuperman et al., 2013; Nag et al., 2013 \\
\hline Computational thinking skills & Sullivan et al., 2013 \\
\hline $\begin{array}{l}\text { Analytical thinking skills; thinking } \\
\text { skills }\end{array}$ & $\begin{array}{l}\text { Cuperman et al., 2013; Nag et al., 2013; Mathers } \\
\text { et al., 2012 }\end{array}$ \\
\hline Developed critical thinking & Mathers et al., 2012 \\
\hline $\begin{array}{l}\text { Social interaction (including children } \\
\text { with autism) Cognitive, emotional, } \\
\text { and social skills }\end{array}$ & $\begin{array}{l}\text { Huskens et al., 2013; Jordan et al., 2013; Fridin, } \\
\text { 2014; Mills et al., 2013 }\end{array}$ \\
\hline Improving children's motor skills & Fridin, 2014 \\
\hline Attention improving skills & Jordan et al., 2013 \\
\hline English reading skills & Hung et al., 2013 \\
\hline $\begin{array}{l}\text { Educational process skills: evaluative } \\
\text { solution, generation of hypotheses and } \\
\text { control of the variables }\end{array}$ & De Cristoforis et al., 2013 \\
\hline $\begin{array}{l}\text { Leadership, team-building, teamwork, } \\
\text { strategy-making skills, collaboration } \\
\text { skills }\end{array}$ & $\begin{array}{l}\text { Nag et al., 2013; Mathers et al., 2012; McDonald } \\
\text { et al., 2012; Varney et al., 2012; Nicholas et al., } \\
\text { 2012; McLurkin et al., 2013 }\end{array}$ \\
\hline Problem solving & $\begin{array}{l}\text { Nag et al., 2013; Mills et al., 2013; Mathers et al., } \\
\text { 2012; Varney et al., 2012; Sullivan et al., 2013; } \\
\text { McLurkin et al., 2013 }\end{array}$ \\
\hline Programming skills & $\begin{array}{l}\text { Cuperman et al., 2013; De Cristoforis et al., } \\
\text { 2013; Nag et al., 2013; Howard et al., 2012 }\end{array}$ \\
\hline Literacy and numeracy skills & McDonald et al., 2012; \\
\hline Presentation skills & Varney et al., 2012 \\
\hline Logical skills & Varney et al., 2012; Nicholas et al., 2012 \\
\hline
\end{tabular}

It should be noted that, compared to the results of the review by Benitti, cognitive skills have been mentioned by one article only, whereas even 6 articles of the present review have noted the fact of formation of cognitive skills. Team work skills have also been mentioned in 6 articles. This review has identified the formation of such skills as motor skills, reading, writing and computational skills, which are absent from the review by Benitti. 


\section{The spectrum of benefits acquired by educational robots}

The findings of all articles demonstrated the benefits acquired by learning aided by educational robots. Cuperman et al., 2013 claimed that $78 \%$ of students who had not yet been engaged in practice believed that practice involving robotic models would be useful. Upon completion of the course, all pupils claimed that practice involving robotic models, in particular, robots for design and creation, indeed helped them learn concepts of natural science and technology.

Huskens et al., (2013) have described the ability of a robot to create a predictable and simple situation of social interaction, which relieves stress and pressure incurred by children with ADHD during the interaction with other people, and allows us to create a much more pleasant and effective learning environment.

Statistical calculations in the study of De Cristoforis et al., 2013 showed that over $35 \%$ of students, who had participated in the activity, were studying under the graduate program of Information Science and Technology. These results suggest rather a significant impact of this activity on enrollment of students into STEM-related programs.

Nag et al., (2013) have noted that over $85 \%$ of mentors and pupils acquired a significantly positive improvement in the areas of STEM and leadership skills. According to the survey results, over $75 \%$ of respondents claimed to have improved skills in mathematics, physics, and programming, while over $90 \%$ claimed to have improved leadership skills and skills in the development of strategy.

McDonald et al., (2012) wrote that development of literacy and computational skills was very positive as well. Children encountered new words related to construction, colours, preposition, place, numbers and more complex words, used in engineering. They could operate these concepts beyond the school context as well. Discoveries related to the development of skills in interpersonal communication were most surprising. Children negotiated and learnt to manage difficulties in communication with peers. Although such concepts as taking turns, sharing and sticking to the assigned roles were sometimes difficult to learn, children could work in groups for more efficient mastering of these modes of behavior during the implementation period of the project. This conclusion was most surprising and pleasing to the class tutor.

Varney et al., have stated that $39.8 \%$ of pupils had satisfactory assessments in mathematics, while $11.4 \%$ of pupils had the lowest assessment scores during the period of three years (2002-2004) before the introduction of the program into the school. Within three years (2007-2009) after the introduction of the program into the school, $91.2 \%$ of pupils on average received a sufficient assessment in mathematics, and none of them received the lowest scores.

Howard et al., (2012) noted that one of the greatest factors of the effect of the interface was a robot motion feedback signal involving turns to the left and to the right, which used to be incomprehensible to pupils (children with eyesight disorders). The main findings and conclusions of the selected articles are presented in Table 8. 
Table 8. Main findings and conclusions in robotics-aided education.

\begin{tabular}{|c|c|}
\hline Main findings & Sources \\
\hline $\begin{array}{l}\text { The design and construction of a robotic model gives } \\
\text { a great benefit to pupils, which cannot be obtained } \\
\text { only by analyzing models built by others. }\end{array}$ & Cuperman et al., 2013; \\
\hline $\begin{array}{l}\text { The interplay between construction and inquiry in the } \\
\text { creation of a robotic model serves as a motivating } \\
\text { factor for learning of both science and technology. }\end{array}$ & $\begin{array}{l}\text { Cuperman et al., 2013; } \\
\text { Hung et al., 2013; De } \\
\text { Cristoforis et al., 2013; } \\
\text { McDonald et al., 2012; v }\end{array}$ \\
\hline $\begin{array}{l}\text { The practice of creating robotic models by rapid } \\
\text { prototyping is an effective learning strategy. }\end{array}$ & Cuperman et al., 2013 \\
\hline $\begin{array}{l}\text { Due to the robotic modeling project pupils can } \\
\text { acquire knowledge and skills in science and } \\
\text { technology as well as skills of learning with models, } \\
\text { skills that are considered to be important components } \\
\text { of science literacy. }\end{array}$ & nan et al., 2013 \\
\hline $\begin{array}{l}\text { The use of robot aid is effective in promoting self- } \\
\text { initiated questions of children or adults with an } \\
\text { autistic disorder syndrome. }\end{array}$ & $\begin{array}{l}\text { Huskens et al., 2013; } \\
\text { Jordan et al., } 2013\end{array}$ \\
\hline $\begin{array}{l}\text { While creating robotics models children's social } \\
\text { speech has significantly improved. }\end{array}$ & $\begin{array}{l}\text { Mills et al., 2013; Hung et } \\
\text { al., } 2013\end{array}$ \\
\hline $\begin{array}{l}\text { A robot teaching assistant for the use in language } \\
\text { learning activities has significantly improved } \\
\text { students' learning motivation and learning efficiency. }\end{array}$ & $\begin{array}{l}\text { Hung et al., 2013; } \\
\text { McDonald et al., 2012; } \\
\text { McLurkin et al., } 2013\end{array}$ \\
\hline $\begin{array}{l}\text { Through the problem-based learning and complex } \\
\text { robotic (satellites) programming students have } \\
\text { significantly improved their mathematics, physics, } \\
\text { strategical planning, and communication skills. }\end{array}$ & $\begin{array}{l}\text { Nag et al., 2013; Mathers } \\
\text { et al., } 2012\end{array}$ \\
\hline $\begin{array}{l}\text { The use of robotics develops pupils' understanding of } \\
\text { fundamental engineering concepts. }\end{array}$ & $\begin{array}{l}\text { McDonald et al., 2012; } \\
\text { McLurkin et al., } 2013\end{array}$ \\
\hline $\begin{array}{l}\text { While constructing robotics models the children's } \\
\text { mathematics and science skills have improved, pupils } \\
\text { have acquired a deeper understanding of } \\
\text { mathematical and science concepts. }\end{array}$ & $\begin{array}{l}\text { Varney et al., 2012; } \\
\text { Meyers et al., } 2012\end{array}$ \\
\hline $\begin{array}{l}\text { Robotics lessons have the influence on students } \\
\text { future career. }\end{array}$ & Howard et al., 2012 \\
\hline $\begin{array}{l}\text { Early age children have the emotional satisfaction } \\
\text { while playing with robot humanoids. }\end{array}$ & Fridin, 2014 \\
\hline $\begin{array}{l}\text { Affordances of the robotics environment promote the } \\
\text { utilization of science literacy-based thinking and } \\
\text { leads to increased systems understanding. }\end{array}$ & Sullivan et al., 2013 \\
\hline
\end{tabular}

The review has shown that nearly all the articles view robotics as a tool that enhances pupils' motivation to learn which determines the effectiveness of learning (Table 9). 
Table 9. Educational robots as a tool to motivate pupils to learn.

\begin{tabular}{|c|c|}
\hline Learning motivation & Source \\
\hline $\begin{array}{l}\text { "The students were highly motivated to learn scientific and } \\
\text { technological concepts and perform hands on activities" }\end{array}$ & $\begin{array}{l}\text { Cuperman et al., } \\
2013\end{array}$ \\
\hline Robots are engaging and motivate children with ASD to interact & $\begin{array}{l}\text { Huskens et al., } \\
2013 \\
\text { Jordan et al., } 2013\end{array}$ \\
\hline $\begin{array}{l}\text { "Students were also asked the question "How much has your } \\
\text { inclination towards STEM increased due to the program?" on a } \\
\text { Likert scale (11/4Not increased at all, } 2 \frac{1}{4} 4 \text { Not much, } 31 / 4 \text { A noticeable } \\
\text { amount, } 4 \frac{1}{4} \text { Significantly, } 51 / 4 \text { I am now certain of a career in STEM) } \\
\text { to which their median response was } 3.89 \% \text { of the participants in } \\
2011 \text { reported a measurable increase in STEM interest due to the } \\
\text { program based on this question, and } 15 \% \text { declared, "I am now certain } \\
\text { of a career in STEM!"." }\end{array}$ & Nag et al., 2013 \\
\hline $\begin{array}{l}\text { "To promote higher order thinking skills and deeper } \\
\text { learning“ }\end{array}$ & Mathers et al., 2012 \\
\hline $\begin{array}{l}\text { "With regard to student engagement, participants were motivated and } \\
\text { engaged in the project and demonstrated their ability to participate in } \\
\text { and complete the tasks." }\end{array}$ & $\begin{array}{l}\text { McDonald et al., } \\
2012\end{array}$ \\
\hline $\begin{array}{l}\text { "Data collected from the previous program graduates indicate that } \\
\text { they are still interested in STEM topics, they remember the program } \\
\text { well, they remember the material presented by the program, and they } \\
\text { retain a high opinion of the program." }\end{array}$ & Varney et al., 2012 \\
\hline $\begin{array}{l}\text { Teachers from } 4 \text { schools noted a great value of inclusion of all } \\
\text { students, only one school for children from disfunctional families } \\
\text { with deep-seated learning and behavioral difficulties could not be } \\
\text { included in the activities, had the lack of enthusiasm. }\end{array}$ & $\begin{array}{l}\text { Nicholas et al., } \\
2012\end{array}$ \\
\hline $\begin{array}{l}\text { Robotics-based programming activities encourage students with } \\
\text { visual impairments in the computing fields at the precollege level. }\end{array}$ & Howard et al., 2012 \\
\hline $\begin{array}{l}\text { "The storytelling robot successfully promoted children's emotional } \\
\text { involvement in the learning process" }\end{array}$ & Fridin, 2014 \\
\hline
\end{tabular}

The TASEM program is an effective tool for developing pupils' character, as this encourages and teaches them to use team skills in the development of own robots. Pupils, taught according to this program, understood the principle of team work better and engaged in STEM discussions taking a wiser position (Varney et al., 2012). All pupils of higher grades were more interested in the practical activity of model development during the course rather than use of ready-made models (Cuperman et al., 2013).

In order to increase the efficiency of learning, teachers' training must be taken into account as well. Benitti noted that, in order to use the educational robots in classes, teachers must be well trained or have a team of assistants for the organized activities (Benitti, 2012). Aspects of teacher training were also identified during the analysis of the studies (Table 10). 
Table 10. Teacher training.

\begin{tabular}{|c|c|}
\hline Teacher training & Source \\
\hline $\begin{array}{l}\text { All prospective teachers were very interested in the } \\
\text { development of actual computer models and their use as a } \\
\text { teaching aid. } \\
\text { Over } 83 \% \text { of prospective teachers recommend using } \\
\text { demonstrative and experimental activities with finished } \\
\text { models in their classes, while all pupils recommend } \\
\text { developing models as part of research activity. Prospective } \\
\text { teachers recognized the benefits of learning aided by models, } \\
\text { in particular, those that visualize dynamic processes. } \\
\text { Prospective teachers stated that development of models } \\
\text { was easier than expected, and their educational benefit } \\
\text { justifies the efforts. }\end{array}$ & $\begin{array}{l}\text { Cuperman et al., } \\
2013\end{array}$ \\
\hline $\begin{array}{l}\text { Professional development workshops on use of robots are } \\
\text { introduced one year before the launch of the study. }\end{array}$ & Mills et al., 2013 \\
\hline $\begin{array}{l}\text { Teachers are provided with all information needed to prepare } \\
\text { for the lesson, including lesson plans, Power Point } \\
\text { presentation, hands-on manuals and assessment tasks. This } \\
\text { material helps teachers present new material and engage the } \\
\text { pupils in activities by using the new methodology. }\end{array}$ & $\begin{array}{l}\text { Mathers et al., } \\
2012\end{array}$ \\
\hline $\begin{array}{l}\text { The main components needed for introduction of this program } \\
\text { into other schools are computers, Lego Mindstorms kits and } \\
\text { special instructors. Instructors can be trained to teach the } \\
\text { program in any part of the country, teleconferencing may be } \\
\text { used for holding demonstrations, presenting additional } \\
\text { lectures and providing the means for communication between } \\
\text { the learners and university community. }\end{array}$ & $\begin{array}{l}\text { Varney } \\
2012\end{array}$ \\
\hline $\begin{array}{l}\text { The study has shown that the greatest issue faced by the } \\
\text { teachers is ability of detecting the wrong link rather than } \\
\text { TPACK (technological pedagogical content knowledge). } \\
\text { Conclusion on the evaluation of professional development: } \\
\text { where the expert support is inaccessible, the teacher needs a } \\
\text { network and regular meetings to be able to exchange his/her } \\
\text { own or pupils' experience, or even perform the actual } \\
\text { construction. With the teachers becoming more skilled in } \\
\text { terms of the content of mechatronics and pedagogy, schools } \\
\text { should initiate the projects targeted deeper into their } \\
\text { curriculum not only in terms of better funding to acquire more } \\
\text { components for building more complex equipment, but also } \\
\text { by analyzing how the listed TPCK aims could find their place } \\
\text { in the curriculum of mechatronics. }\end{array}$ & $\begin{array}{l}\text { Nicholas et al., } \\
2012\end{array}$ \\
\hline $\begin{array}{l}3 \text { teacher trainings involved 3-hour work with researchers' } \\
\text { assistants, dedicated to learning the language of programming } \\
\text { and use of the robot kits. Teachers also received technical and } \\
\text { assessment-related support. }\end{array}$ & $\begin{array}{l}\text { Sullivan et al., } \\
2013\end{array}$ \\
\hline
\end{tabular}




\subsection{Which teaching methods (teaching strategy) are applied in the educational process?}

The review of teaching methods, applied by using robots (Altin et al., 2013), has shown that the most popular methods are problem-based, constructivist and competition-based learning. Besides these main methods, other methods used are discovery learning, communication-based learning, project-based learning, and competition-based learning. In terms of teaching the main engineering concepts (design, simulation, limitations, innovations, system optimization, experimentation, prototypes, compromise, analysis, problem solving, functionality, visualization and efficiency), usually taught at the pre-college level, Riojas (Riojas et al., 2012) identified the following three proper teaching methods: 1) direct instruction, 2) problem / inquiry-based learning, and 3) project-based learning. Direct instruction is a deductive teaching method viewing learning as a function of change of pupils' longterm memory. Problem and inquiry-based inductive teaching methods share a lot of common features when used in teaching engineering at the pre-college level. As a result, these two methodologies are seldom viewed as separate. The project-based learning method is an inductive teaching method, when students apply their knowledge. Of all the above mentioned teaching methods, competition-based learning was the most efficient method of using robots in mathematics, physics, and other subjects (Altin et al., 2013). This fact was proven by the systematic analysis conducted earlier (Benitti, 2012). Competitions, on the other hand, are focused on a certain group of learners only, robot competitions are rather expensive to hold, and the number of participants is limited due to financial reasons (Altin et al., 2013). In view of this limitation, effective ways of using robots in science, technology, and engineeringrelated classes for all learners must be explored. Benefits provided by robots must be applied to a wider audience (Altin et al., 2013). To this end, in order to expand the effect of the summer program, the proposed program was altered, i.e. one-week summer program was replaced with the primary school program for the third grade. This expanded the scope of the program and engaged students that were not yet interested in STEM subjects (Varney et al., 2012). Hung I-Chun noted in his study that educational robots may enhance pupil's motivation to learn, but this learning motivation would be difficult to maintain and be subject to gradual reduction, if new technologies were not introduced into the teaching strategy (Hung et al., 2013). The effect will be minimal, where robots are not included in the general curriculum, no methods or tools are used to assess the outcomes of the curriculum. Therefore, two ways of inclusion of robots into the curriculum should be used: robots as a learning object and robots as a tool to learn other subjects (Altin et al., 2013). Use of robots in the educational process should not be a one-time project, but rather a continued and progressing process from the primary school all the way to the university level (Lye et al., 2013). New methods that empower the use of robots in classes are important. Students' interest in robotics is an important factor of the learning process that allows achieving the learning goals. 
Robots with special sensors and communication systems, and the innovative robotbased curriculum encourage new ways of interaction among pupils (McLurkin et al., 2013). Effective integration of robots as a tool into the teaching process could lead to a shift of the teacher's traditional role from the teacher who passes the knowledge to the teacher as a learning assistant, organizer, leader, learning partner, helper and intermediary at all educational stages, including kindergarten (Fridin, 2014). Hence, robots could be claimed to have great potential that is yet to be fully discovered. Studies selected by the authors have offered the following factors, important for effective integration of robots into the curricula:

1. Varney et al., (2012) identified 3 aspects of successful integration of the program: 1) graduate students involved as instructors, 2) pupils provided with the possibility to have a direct communication with a university professor by means of videoconferences, 3) presentation of works by pupils at the end of each year at the school level. The last aspect inspires interest of other learners in STEM subjects at the same school.

2. Teachers' attitude is the only critical internal "variable" in the success formula of introduction of the program. This fact has been best demonstrated by comparison between two schools that are completely different by teaching methods (behaviorist versus humanist), levels of experience (experts versus beginners) and infrastructure (advanced versus beginner), but both managed to successfully achieve the project results (Nicholas et al., 2012). The strategy of implementation of the program in school was also important. A possibility to successfully introduce the program into the school curriculum was clearly determined by the common climate and decision-making processes in schools. (Nicholas et al., 2012).

3. Nicholas et al., (2012) identified internal and external factors that have influence on the implementation of robotics in a school. Internal factors are: teaching methods, teachers' attitude, program evaluation. External factors are: 1) infrastructure and computer access, 2) time dedicated to organization and planning 3) need for more help by experts, 4) need for more funds for professional development, 5) need for purchase of more materials for constructing more advanced devices. Different methods of implementation of the program into the educational curriculum have been evaluated in 5 schools.

The following positive aspects of integration of robotics into the educational process have been noticed:

1. Possibilities for simulation by using robot kits that enable a combination of engineering design and research in natural sciences into integrated learning activities (Cuperman et al., 2013).

2. Encouragement of the use of technologies to reduce the gap between pupils from socially supported and self-sustaining families. Help in the development of younger learners' skills for those who do not have favorable conditions of digital access. (McDonald et al., 2012).

3. Involvement of pupils from different social, economic, and cultural layers (Varney et al., 2012). 


\section{Conclusion}

Robotics and a variety of developed tools have led to both a more efficient use of robotics for different subjects and application to a broader range of ages of pupils.

The results of the study have shown that the scope of the research on the use of robotics has extended. During the research it was noticed that more publications and more varied research on this topic could be found. Therefore, the authors believe that robotics is an emerging research topic as more researchers have been involved in this topic recently. Based on literature review the application of robotics in schools continues to expand and encompasses not only STEM, but also non-STEM subjects (social sciences and humanities). A wider range of skills, developed during the use of robotics in education, has been noticed as well. The diversity of robotic tools used in the educational process and the range of learners' age have expanded. The tendency of including robotics into classroom activities and establishing the links between robotics and curriculum has been noticed, but more empirical research and the related findings are needed. Moreover, the use of robotics is an alternative way of teaching and learning subjects that, as demonstrated by the study, are not closely related to the area of robotics. This teaching aid may find a wide application in the educational context; however, the specific teaching methods, adequate for using educational robots in the process, must be identified and linked to the general curricula, because, as study reveals, today the most commonly used method of teaching is competition-based learning in non-formal education.

By identifying the prospects for scientific research related to robotics in education the attempt was to study the potential and application of educational robots in the Lithuanian educational context. This article has opened new perspectives for future research with the focus on pupils' experience, related to educational robots, by linking this experience to the general curricula and identifying adequate educational methods. With reference to the systematic review it can be concluded that the most suitable teaching methods are: the problem / inquiry-based learning, project-based learning and competition-based learning.

Based on the results of the systematic review areas of Lithuania's curriculum in which educational robots suggested to be applied are: languages, mathematics, science education, technologies and for development of general competencies, cognition of the world, education for the deaf and hard of hearing as well. Other areas need more research.

Recently, STEM ideas and their specific implementation have been entering formal and non-formal education in Lithuanian schools. In June to September 2016, the "Academy of Robotics" conducted their project "Correspondence of Teaching Methods to Development of STEM Abilities". The project involved development of the RT-based guidebook of good practice in STEM learning and RT-based learning methodology. The conducted systematic review has provided useful information for the preparation of those documents. 


\section{References}

Altin, H., Pedaste, M. (2013). Learning approaches to applying robotics in science education. Journal of baltic science education, 12(3), 365-377.

Benitti, F. B. V. (2012). Exploring the educational potential of robotics in schools: A systematic review. Computers \& Education, 58(3), 978-988.

Cuperman, D., Verner, I. M. (2013). Learning through creating robotic models of biological systems. International journal of technology and design education, 23(4), 849-866.

De Cristoforis, P., Pedre, S., Nitsche, M., Fischer, T., Pessacg, F., Di Pietro, C. (2013). A Behavior-Based Approach for Educational Robotics Activities. IEEE transactions on education, 56(1), 61-66.

Fridin, M. (2014). Storytelling by a kindergarten social assistive robot: A tool for constructive learning in preschool education. Computers \& education, 70, 53-64.

Howard, A. M., Park, Ch. H., Remy, S. (2012). Using Haptic and Auditory Interaction Tools to Engage Students with Visual Impairments in Robot Programming Activities. IEEE transactions on learning technologies, 5(1), 87-95.

Hung, I-Ch., Chao, K-J., Lee, L., Chen, N-Sh. (2013). Designing a robot teaching assistant for enhancing and sustaining learning motivation. Interactive learning environments, 21(2), 156-171.

Huskens, B., Verschuur, R., Gillesen, J., Didden, R., Barakova, E. (2013). Promoting questionasking in school-aged children with autism spectrum disorders: Effectiveness of a robot intervention compared to a human-trainer intervention. Developmental neurorehabilitation, 16(5), 345-356.

Jordan, K., King, M., Hellersteth, S., Wiren, A., Mulligan, H. (2013). Feasibility of using a humanoid robot for enhancing attention and social skills in adolescents with autism spectrum disorder. International journal of rehabilitation research, 36(3), 221-227.

Kitchenham, B. (2004). Procedures for performing systematic reviews. Joint technical report Software Engineering Group. Keele University, United Kingdom and Empirical Software Engineering, National ICT Australia Ltd.

Lye, N. Ch., Wong, K. W., Chiou, A. (2013). Framework for educational robotics: a multiphase approach to enhance user learning in a competitive arena. Interactive learning environments, 21(2), 142-155.

Mathers, N., Goktogen, A., Rankin, J., Anderson, M. (2012). Robotic Mission to Mars: Handson, minds-on, web-based learning. Acta astronautica, 80, 124-131.

McDonald, S., Howell, J. (2012). Watching, creating and achieving: Creative technologies as a conduit for learning in the early years. British journal of educational technology, 43(4), 641-651.

McLurkin, J., Rykowski, J., John, M., Kaseman, Q., Lynch, A. J. (2013). Using Multi-Robot Systems for Engineering Education: Teaching and Outreach With Large Numbers of an Advanced, Low-Cost Robot. IEEE transactions on education, 56(1), 24-33.

Meyers, K. L., Goodrich, V., Brockman, J. (2012). I2D2: Imagination, Innovation, Discovery, and Design. International journal of engineering education, 28(5), 1109-1118.

Mills, K. A., Chandra, V., Park, J. Y. (2013). The architecture of children's use of language and tools when problem solving collaboratively with robotics. Australian educational researcher, 40(3), 315-337.

Nag, S., Katz, J. G., Saenz-Otero, A. (2013). Collaborative gaming and competition for CSSTEM education using SPHERES Zero Robotics. Acta astronautica, 83, 145-174.

Nicholas, H., Ng, W. (2012). Factors influencing the uptake of a mechatronics curriculum initiative in five Australian secondary schools. International journal of technology and design education, 22(1), 65-90.

Papert, S. (1993). Mindstorms: Children, computers, and powerful ideas. 2nd ed. New York, NY: Basic Books. 
Riojas, M., Lysecky, S., Rozenblit, J. (2012). Educational Technologies for Precollege Engineering Education. IEEE transactions on learning technologies, 5(1), 20-37.

Sullivan, F. R. (2008). Robotics and science literacy: thinking skills, science process skills and systems understanding. Journal of Research in Science Teaching, 45(3), 373-394.

Sullivan, A., Bers, M. U. (2013). Gender differences in kindergarteners' robotics and programming achievement. International journal of technology and design education, 23(3), 691-702.

Varney, M. W., Janoudi, A., Aslam, D. M., Graham, D. (2012). Building Young Engineers: TASEM for Third Graders in Woodcreek Magnet Elementary School. IEEE transactions on education, 55(1), 78-82.

Williams, D., Ma, Y., Prejean, L., Lai, G., Ford, M. (2007). Acquisition of physics content knowledge and scientific inquiry skills in a robotics summer camp. Journal of Research on Technology in Education, 40(2), 201-216.

Received April 14, 2016, revised January 5, 2017, accepted February 14, 2017 